\title{
Agronomic characteristics and yield of organic maize straw intercropped with perennial green manures ${ }^{1}$
}

\author{
Ana Carolina Costa Arantes ${ }^{2}$, Anastácia Fontanetti ${ }^{2}$, \\ Marcio Roberto Soares ${ }^{2}$, Francisco José da Silva $\mathrm{Neto}^{2}$, Alexandre Gonçalves Próspero ${ }^{2}$
}

\begin{abstract}
Maize intercropped with perennial green manure is an option to promote soil coverage, control weeds and recycle soil nutrients, in an organic system. This study aimed at evaluating the agronomic characteristics and yield of grains and organic maize straw intercropped with perennial green manures sown at different maize growth stages. A $3 \times 2+1$ factorial design was used, with three perennial species of green manure calopogonium (Calopogonium mucunoides Desv.), tropical kudzu [Pueraria phaseoloides (Roxb.) Benth] and perennial soy [Neonotonia wightii (Wight \& Arn) Lackey] - and two green manure sowing times - at the maize V4 (four expanded leaves) and VT (bolting) stages - plus a control treatment (maize monoculture). A randomized blocks design, with four replications, was used. Soil coverage, production of green manures dry matter and weeds, and maize growth and production variables were evaluated. The sowing of green manures at the V4 stage had a higher percentage of soil coverage, in relation to the VT stage. Calopogonium, when compared to the other green manure species, had the highest percentage of soil coverage $(35.63 \%)$ and dry matter $\left(1.0 \mathrm{Mg} \mathrm{ha}^{-1}\right)$. Perennial green manures grown intercropped with maize did not affect growth, grain yield and maize straw. However, they were not effective in suppressing weeds.
\end{abstract}

KEY-WORDS: Zea mays L.; Calopogonium mucunoides Desv.; Pueraria phaseoloides (Roxb.) Benth; Neonotonia wightii (Wight \& Arn) Lackey.

\section{INTRODUCTION}

Brazil is the third largest grain producer in the world (Conab 2016). The main destination of maize grains is animal feeding, representing $60-80 \%$ of the total production (Cruz et al. 2006). In the organic systems, the production of maize grains is low and has a low regularity of supply, which might impair the production chains of meat, eggs and milk.

\section{RESUMO}

Características agronômicas e produtividade de palhada de milho orgânico em consórcio com adubos verdes perenes

O consórcio de milho com adubo verde perene é uma opção para promover a cobertura do solo, controlar plantas espontâneas e reciclar nutrientes do solo, em sistema orgânico. Objetivou-se avaliar as características agronômicas e produtividade de grãos e de palhada de milho orgânico em consórcio com adubos verdes perenes, semeados em diferentes estádios fenológicos do milho. Utilizou-se esquema fatorial $3 \times 2+1$, com três espécies perenes de adubos verdes - calopogônio (Calopogonium mucunoides Desv.), puerária [Pueraria phaseoloides (Roxb.) Benth] e soja-perene [Neonotonia wightii (Wight \& Arn) Lackey] - e duas épocas de semeadura dos adubos verdes - estádios V4 (quatro folhas expandidas) e VT (pendoamento) do milho - mais um tratamento controle (milho em monocultivo). Utilizou-se delineamento em blocos casualizados, com quatro repetições. Avaliou-se a cobertura do solo, produção de massa seca dos adubos verdes e das plantas espontâneas e variáveis de crescimento e produção do milho. A semeadura dos adubos verdes, no estádio V4, proporcionou maior porcentagem de cobertura do solo, em relação ao VT. O calopogônio, quando comparado aos demais adubos verdes, apresentou maior porcentagem de cobertura do solo (35,63\%) e massa seca $\left(1,0 \mathrm{Mg} \mathrm{ha}^{-1}\right)$. Os adubos verdes perenes cultivados em consórcio com milho não interferiram no crescimento, produtividade de grãos e palhada do milho. Porém, não foram eficientes na supressão das plantas espontâneas.

PALAVRAS-CHAVE: Zea mays L.; Calopogonium mucunoides Desv.; Pueraria phaseoloides (Roxb.) Benth; Neonotonia wightii (Wight \& Arn) Lackey.

Livestock depends heavily on maize grains and is the predominant activity in $41.7 \%$ of the Brazilian organic farms (IBGE 2009).

Information related to management, production and performance of maize cultivars in organic systems is still scarce. This makes cultivation difficult and may reduce grain yield in organic systems.

Organic farming aims at maintaining and improving the physical, chemical and biological

1. Manuscript received in May/2016 and accepted for publication in Jul./2016 (http://dx.doi.org/10.1590/1983-40632016v4641054).

2. Universidade Federal de São Carlos, Centro de Ciências Agrárias, Araras, SP, Brazil.E-mails: accarantes@gmail.com, anastacia@cca.ufscar.br,mrsoares@cca.ufscar.br, franciscojose331@gmail.com, alexandregprospero@gmail.com. 
characteristics of the soil by increasing organic matter. However, soil turnover is still common among organic grain producers. This practice is attributed to the difficulty in controlling and managing weeds. Soil preparation accelerates degradation processes and the imbalance of characteristics such as soil structure, moisture retention, water infiltration, porosity and organic matter (Stefanoski et al. 2013).

The use of green manures is an economically viable and sustainable alternative, as they are characterized as soil conditioner plants. In addition, they are capable of cycling nutrients for the subsequent culture by mineralizing organic matter, increasing root exudates, organic acids, amino acids and plant hormones, among other substances. The green coverage of the soil also acts as biological activators (Padovan et al. 2013).

Green manures may assist in the management of weeds by acting as a physical barrier on the soil, which reduces the incidence of infrared rays and the thermal amplitude, making it difficult to break the dormancy and germination of photoblastic seeds. In addition, it may also reduce the population of weeds by allelopathy, which consists in the release of secondary metabolites by leaves, decomposition of straw or the root system (Monquero et al. 2009).

The intercropping between plants is an alternative to provide straw. It reduces the effects of soil preparation on the production system, possibly without affecting the main crop, and still maintaining an economic profitability. In addition, the simultaneous cultivation of two or more species can more effectively take advantage of the growth factors in the cropping area (Bezerra et al. 2007). To avoid competition, it is important for green manure plants to have botanical and physiological characteristics different from the main crop. It is also important that they are adapted to the local climate and soil condition (Pantaleão et al. 2012, Padovan et al. 2013).

The cultivation of maize intercropped with green manures, in particular Fabaceae, is widely used, because, in addition to the production of grains, it may increase soil coverage during the development of maize (Borghi \& Crusciol 2007). The intercropping of maize with dwarf pigeonpea (Cajanus cajan L.) and rattlepods (Crotalaria spectabilis Roth) is an interesting system, known as the Santa Brígida System (Oliveira et al. 2010).

The sowing of Fabaceae is a very important aspect for the success of the intercropping, and often depends on its growth habit. For species with a determined growth, and small to medium size, such as Canavalia ensiformis DC. and dwarf pigeonpea, both with an annual cycle, the planting simultaneously with maize has been satisfactory (Perin et al. 2007, Oliveira et al. 2010).

Among the Fabaceae intercropped with maize, perennial Fabaceae remains for a longer period in the area, and, therefore, can vegetative recover the area after long periods of water deficit (Lima et al. 2014). Calopogonium, tropical kudzu and perennial soy are perennial species generally intercropped with maize and fruits (Quaresma et al. 2013, Fontanetti et al. 2014). However, for the decision-making on their use and management, it is important to note that these species have a slow initial growth. They are climber plants (Seprotec 2014) and have a hard seed coat, affecting germination and emergence (Monteiro et al. 2009).

This study aimed at evaluating the agronomic characteristics, grain yield and the organic straw of maize intercropped with perennial green manure sown at different phenological maize stages, as well as to evaluate the development and production of dry matter of green manures and their potential for controlling weeds.

\section{MATERIAL AND METHODS}

The experiment was conducted between December 2014 and July 2015, at the experimental area of the Universidade Federal de São Carlos $\left(22^{\circ} 21^{\prime} \mathrm{S}, 47^{\circ} 23^{\prime} \mathrm{W}\right.$ and altitude of $\left.629 \mathrm{~m}\right)$, in Araras, São Paulo State, Brazil, where the climate is mesothermic $\mathrm{Cwa}$, with hot and humid summers and dry winters, according to the Köppen classification. Climatological data are described in Table 1.

The soil of the experimental area is classified as a dystrophic Red Latosol, with a clayey texture. The chemical characteristics at the 0.0-0.3 m depth layer are: $\mathrm{pH}\left(\mathrm{CaCl}_{2}\right)=5.5 ; \mathrm{P}=14.0 \mathrm{mg} \mathrm{dm}^{-3}$; $\mathrm{K}=4.9 \mathrm{mmol}_{\mathrm{c}} \mathrm{dm}^{-3} ; \mathrm{Ca}=27.3 \mathrm{mmol}_{\mathrm{c}} \mathrm{dm}^{-3} ; \mathrm{Mg}=$ $9.3 \mathrm{mmol}_{\mathrm{c}} \mathrm{dm}^{-3} ; \mathrm{H}+\mathrm{Al}=22.7 \mathrm{mmol}_{\mathrm{c}} \mathrm{dm}^{-3}$; organic matter $=23.3 \mathrm{~g} \mathrm{~kg}^{-1}$; base saturation $=64.0 \%$.

Soil preparation was performed with two plowing processes (disk plow and leveling tractor). Fertilization was carried out using the commercial organic compound Visafertil ${ }^{\circledR}$, at a dose of 9.2 $\mathrm{Mg} \mathrm{ha}^{-1}$ (weight of dry composite), approximately $10.58 \mathrm{~m}^{3} \mathrm{ha}^{-1}$, to meet the needs of maize for 
Table 1. Global radiation data, total and average rainfall, and minimum, maximum and average temperature observed during the months of the experiment.

\begin{tabular}{lccccccc}
\hline \multirow{2}{*}{ Months } & \multicolumn{2}{c}{ Radiation $\left(\mathrm{MJ} \mathrm{m}^{-2}\right)$} & \multicolumn{2}{c}{ Rainfall $(\mathrm{mm})$} & \multicolumn{3}{c}{ Temperature $\left({ }^{\circ} \mathrm{C}\right)$} \\
\cline { 2 - 7 } & Total & Average & Total & Average & Minimum & Maximum & Average \\
\hline Dec./2014 & 631.9 & 20.4 & 218.6 & 7.0 & 18.4 & 31.0 & 24.7 \\
Jan./2015 & 691.3 & 22.3 & 121.8 & 3.9 & 19.9 & 33.3 & 26.6 \\
Feb./2015 & 557.6 & 19.9 & 245.4 & 8.7 & 18.6 & 30.7 & 24.6 \\
Mar./2015 & 513.4 & 16.6 & 173.4 & 5.6 & 18.1 & 28.7 & 23.4 \\
Apr./2015 & 544.4 & 18.1 & 11.2 & 0.4 & 16.2 & 29.9 & 23.1 \\
May/2015 & 405.2 & 13.1 & 67.0 & 2.2 & 14.1 & 25.8 & 20.0 \\
Jun./2015 & 404.0 & 13.0 & 26.2 & 0.9 & 13.6 & 25.3 & 19.5 \\
Jul./2015 & 355.4 & 11.5 & 12.1 & 0.4 & 13.8 & 24.9 & 19.3 \\
\hline
\end{tabular}

Source: Universidade Federal de São Carlos.

nitrogen $\left(120.00 \mathrm{~kg} \mathrm{ha}^{-1}\right)$. Thus, $288.90 \mathrm{~kg} \mathrm{ha}^{-1}$ of $\mathrm{P}_{2} \mathrm{O}_{5}$ and $149.53 \mathrm{~kg} \mathrm{ha}^{-1}$ of $\mathrm{K}_{2} \mathrm{O}$ were applied, aiming at a grain yield of $6.0-8.0 \mathrm{Mg} \mathrm{ha}^{-1}$ (Coelho 2006), according to the chemical characteristics of the compound: density of $0.87 \mathrm{~g} \mathrm{~cm}^{-3} ; \mathrm{pH}\left(\mathrm{H}_{2} \mathrm{O}\right)=$ 8.0; $\mathrm{C}=113.97 \mathrm{mg} \mathrm{cm}^{-3} ; \mathrm{N}=11.31 \mathrm{mg} \mathrm{cm}^{-3} ; \mathrm{P}=$ $11.90 \mathrm{mg} \mathrm{cm}^{-3} ; \mathrm{K}=1.17 \mathrm{mg} \mathrm{cm}^{-3} ; \mathrm{Ca}=6.90 \mathrm{mg} \mathrm{cm}^{-3}$; $\mathrm{Mg}=0.52 \mathrm{mg} \mathrm{cm}^{-3} ; \mathrm{S}=4.36 \mathrm{mg} \mathrm{cm}^{-3} ; \mathrm{Cu}=$ $0.06 \mathrm{mg} \mathrm{cm}^{-3} ; \mathrm{Fe}=0.49 \mathrm{mg} \mathrm{cm}^{-3} ; \mathrm{Mn}=0.45 \mathrm{mg} \mathrm{cm}^{-3}$; $\mathrm{Zn}=0.67 \mathrm{mg} \mathrm{cm}^{-3}$; organic matter $=22.58 \%$; humidity $=37.40 \%$.

A $3 \times 2+1$ factorial design was used. The first factor was the green manure - calopogonium (Calopogonium mucunoides Desv.), tropical kudzu [Pueraria phaseoloides (Roxb.) Benth] and perennial soy [Neonotonia wightii (Wight \& Arn) Lackey] and the second factor was the green manure sowing time - V4 (four expanded leaves of maize) and VT (maize bolting). The control treatment was a maize monoculture. The experimental design consisted of complete randomized blocks, with four replications.

The experimental plot consisted of five rows of maize, $5 \mathrm{~m}$ long, spaced $0.90 \mathrm{~m}$ apart, totaling $18 \mathrm{~m}^{2}$ of internal area per plot, disregarding the borders. Maize (organic AL Avaré cultivar) from the Coordenadoria de Assistência Técnica Integral (CATI), with $70 \%$ of germination, was sown on December 17, 2014, at a density of 10 seeds $\mathrm{m}^{-1}$, for a final population of 70,000 plants ha ${ }^{-1}$. After emergence, thinning was not performed.

Prior to the sowing of green manure, seeds were submitted to dormancy breaking by immersion in deionized water at $80{ }^{\circ} \mathrm{C}$, for $5 \mathrm{~min}$ (Monteiro et al. 2009), and, at each time (V4 and VT), the plots were weeded and then furrows were opened manually in maize inter-rows, $0.45 \mathrm{~m}$ between the sowing row of the green manure and the sowing row of the maize. The green manures were sown at a density of 21 seeds $\mathrm{m}^{-1}$ of calopogonium (C. mucunoides), 60 seeds $\mathrm{m}^{-1}$ of tropical kudzu (P. phaseoloides) and 30 seeds $\mathrm{m}^{-1}$ of perennial soy ( $N$. wightii), according to the culture value (\% purity x \% germination/ 100$)$ of each species seeds.

At the V2-V3 stage (two to three expanded maize leaves), there was an armyworm attack (Spodoptera frugiperda JE Smith) above the level of economic damage. The control was performed with the application of $0.5 \mathrm{~L} \mathrm{ha}^{-1}\left(16.80 \mathrm{~g} \mathrm{ha}^{-1}\right.$ of active ingredient) of the commercial biological insecticide DIPEL WP ${ }^{\circledR}$ (Bacillus thuringiensis var. kurstaki).

Maize, green manure and weed evaluations were performed in the useful area of each plot (three central rows, approximately $9 \mathrm{~m}^{2}$ ), at three different times: R2/R3 stage (milky/doughy grain), R5 stage (chalky grain) and after maize harvest.

At the reproductive stage $\mathrm{R} 2 / \mathrm{R} 3$, the following variables related to maize were measured: height (m), in 10 plants, using a graduated ruler, from the base of the plants to the insertion of the last fully developed leaf; diameter $(\mathrm{cm})$, in 10 plants, using a digital caliper, in the second internode; specific leaf area $\left(\mathrm{cm}^{2} \mathrm{~g}^{-1}\right)$, in two plants, by the average of total leaf area obtained using a portable photoelectric leaf area reader LI-COR $3000 \mathrm{C}$, from the dry weight of the leaves; leaf area index $\left(\mathrm{cm}^{2} \mathrm{~cm}^{-2}\right)$, in two plants, estimated by the ratio between total leaf area and soil space occupied by plants; stem, leaves and total dry matter of maize $\left(\mathrm{kg} \mathrm{ha}^{-1}\right)$, by drying two plants in a forced-air ventilation oven, at $\pm 65^{\circ} \mathrm{C}$, for approximately $72 \mathrm{~h}$; Falker chlorophyll index, in five plants, with two readings of the opposing leaf below the spike, in the second third of the length from the 
base leaf(Basi 2013); and leaves above the upper ear, by counting the fully developed leaves of five plants.

At the reproductive and $\mathrm{R} 5$ stages, the following traits were measured: percentage of coverage $(\%)$ by green manures, by the "intersections method", using a wooden frame $\left(0.25 \mathrm{~m}^{2}\right)$ with a string network cast three times, summing the total number of intersections over the green manure; dry matter $\left(\mathrm{kg} \mathrm{ha}^{-1}\right)$ of green manure and weeds, in three collections, with a template of $0.0625 \mathrm{~m}^{2}$, dried in an oven at $\pm 65{ }^{\circ} \mathrm{C}$; and total dry matter of the intercropping $\left(\mathrm{kg} \mathrm{ha}^{-1}\right)$, by summing the dry matter produced by the maize and the dry matter produced by green manures.

The last evaluations occurred after harvest. They were conducted using grains at a moisture level of $17-21 \%$, at 162 days after emergence (DAE), in the useful area of each plot. The evaluations of production components consisted of final plant stand (plants ha ${ }^{-1}$ ), prolificacy (total number of ears divided by the final plant stand), number of grain rows per ear and number of grains per row in ten ears, grain yield ( $\left.\mathrm{Mg} \mathrm{ha}^{-1}\right)$ and average weight of 100 grains (g), both with moisture corrected to $13 \%$.

The results were submitted to analyses of variance by the F test. Means of maize/green manures intercropping treatments were compared by the Tukey test at $5 \%$, and means of maize/green manures intercropped with maize monoculture were compared, by contrast among means, by the $\mathrm{F}$ test at $5 \%$. Analyses were performed using the Sisvar for Windows software, version 4.

\section{RESULTS AND DISCUSSION}

The variables plant height, stem diameter, specific leaf area, leaf area index, culm dry matter, leaf dry matter and total dry matter of maize, Falker chlorophyll index and leaves above the upper ear showed no significant differences in intercropping systems and between the maize/green manure intercropping versus maize monoculture.

All variables mentioned are sensitive to changes, according to the cropping system, such as availability of light, water and nutrients, and may indicate the establishment of a competition. This was not observed in this study. Maize is considered a successful competitor, in relation to smaller plants, mainly due to its greater dry matter accumulation rate at early stages of development (Silva et al. 2004).
The number of leaves above the ear, for example, directly influences grain yield, since approximately $50 \%$ of carbohydrates retained in maize grains are obtained from leaves located in the upper part of the culm (Alvim et al. 2010). The fact that there were no differences between intercropping and maize monoculture systems, regarding the average number of leaves above the ear, which was on average 6.1 , indicates that there was probably no competition between green manures and maize.

For the variables dry matter and percentage of soil coverage by the green manures, there was a significant interaction effect between green manures and sowing times. Calopogonium stood out, showing the highest production of dry matter, in relation to the other green manures, when sown at the V4 stage. However, this was not observed when Calopogonium was sown at the VT stage. At this stage, there was no difference between green manures, regarding production of dry matter (Table 2).

According to Lima et al. (2014), the green manures studied have a slow initial growth. Moreover, uneven emergence and establishment of tropical kudzu and perennial soy in the field were observed. This was not verified for Calopogonium, which favored its establishment and increased production of dry matter, when sown at the V4 stage. Calopogonium has a moderate tolerance to shade (Seprotec 2014), what may have hindered its establishment and the production of dry matter, when sown at the maize VT stage.

Fontanetti et al. (2014), evaluating maize intercropped with Calopogonium, in the same experimental area of this study, during the 2013/2014 harvest, observed a production of $260 \mathrm{~kg} \mathrm{ha}^{-1}$ of dry matter, when Calopogonium was sown at $35 \mathrm{DAE}$ of maize (V4 stage), and 1,410 $\mathrm{kg} \mathrm{ha}^{-1}$ of dry matter, when Calopogonium was sown simultaneously

Table 2. Averages for dry matter and percentage of soil coverage for green manures sown at the maize V4 and VT growth stages.

\begin{tabular}{lcrcc}
\hline \multirow{2}{*}{ Green manure } & \multicolumn{2}{c}{ Dry matter $\left(\mathrm{kg} \mathrm{ha}^{-1}\right)$} & \multicolumn{2}{c}{ Soil coverage $(\%)$} \\
\cline { 2 - 5 } & $\mathrm{V} 4$ & $\mathrm{VT}$ & $\mathrm{V} 4$ & $\mathrm{VT}$ \\
\hline Calopogonium & $1,002.0 \mathrm{Aa}^{1}$ & $257.6 \mathrm{Ab}$ & $35.6 \mathrm{Aa}$ & $11.8 \mathrm{Ab}$ \\
Tropical kudzu & $278.8 \mathrm{Ba}$ & $62.4 \mathrm{Aa}$ & $19.7 \mathrm{Ba}$ & $7.4 \mathrm{Ab}$ \\
Perennial soy & $161.6 \mathrm{Ba}$ & $81.2 \mathrm{Aa}$ & $14.5 \mathrm{Ba}$ & $5.0 \mathrm{Ab}$ \\
\hline $\mathrm{CV}(\%)$ & \multicolumn{2}{c}{60.5} & \multicolumn{2}{c}{32.7} \\
\hline
\end{tabular}

${ }^{1}$ Means followed by the same uppercase letter, in the columns, and lowercase letters, in the lines, do not differ by the Tukey test at $5 \%$. 
with maize. The authors stressed that this difference in dry matter was due to the green manures longer development and growth time.

The Calopogonium dry matter observed in this study $\left(1,002.0 \mathrm{~kg} \mathrm{ha}^{-1}\right)$ is lower than that found by Pantaleão et al. (2012), in a monoculture system, in which this species had $1,300.0 \mathrm{~kg} \mathrm{ha}^{-1}$ of dry matter, at 93 days after sowing (DAS).

Similarly to dry matter, the percentage of soil coverage by green manure reached the highest value for Calopogonium sown at the maize V4 stage, with approximately $36 \%$ of soil coverage (Table 2 ).

Soil coverage provided by perennial green manures was also evaluated by Quaresma et al. (2013), with results similar to this study. Calopogonium provided a higher percentage of soil coverage, in relation to tropical kudzu. Fontanetti et al. (2014) found a percentage of soil coverage of $52 \%$, for Calopogonium sown at the maize V4 stage. On the other hand, Teodoro et al. (2011), evaluating different green manures, including monocultures of Calopogonium, perennial soy, tropical kudzu, forage peanut and stylosanthes, found that Calopogonium, forage peanut and tropical kudzu completely covered the soil $(100 \%)$ at 120 DAS of green manure.

In the study by Teodoro et al. (2011), it must be emphasized that green manures were grown in monoculture, that is, they did not compete for production factors (light, water and nutrients) with maize plants, and the spacing between sowing lines was $0.40 \mathrm{~m}$. These factors likely contributed to a higher soil cover.

Lima et al. (2014) suggested increasing the seeding density of green manures and adjusting the arrangement (spacing) of the plants as options to increase soil coverage by the same green manures evaluated in this experiment. Increasing density may anticipate a full soil coverage, favoring the competition with weeds.

Regarding the production of dry matter by weeds, there was no significant effect of green manures, sowing times and interactions between green manures and sowing dates and between the intercropping of maize/green manures versus maize monoculture. There was an average of $1,217.3 \mathrm{~kg} \mathrm{ha}^{-1}$ of weed dry matter, regardless of treatment. Probably, the uneven emergence and the slow initial growth of green manures allowed the establishment and development of weeds, which were more efficient competitors than the maize and the green manures studied.
However, it is noteworthy that, for being perennial green manures, they may have a suppressive effect on weeds over time. Lima et al. (2014) reported that Calopogonium, tropical kudzu and perennial soy, despite having slow initial growth, may exert a suppressive effect on weeds, because of the competition for light, water and nutrients, or even by releasing allelopathic substances. This happens with Calopogonium, which can eliminate weeds after 90 days of sowing in monoculture through physical or allelopathic elimination (Teodoro et al. 2011).

The total production of dry matter in intercropping systems was not influenced by the species of green manure and sowing dates. Although the Calopogonium produced a dry matter amount higher than the other green manures, when sown at the maize V4 stage (Table 2), the sum of the production of dry matter in intercropping systems $\left(6,989.9 \mathrm{~kg} \mathrm{ha}^{-1}\right)$ was similar, even if compared to the production of dry matter by maize monoculture $\left(6,878.8 \mathrm{~kg} \mathrm{ha}^{-1}\right)$.

According to Nunes et al. (2006), at least $6.00 \mathrm{Mg} \mathrm{ha}^{-1}$ of dry matter (straw) are required to benefit the productive system, in order to provide a good soil coverage, maintenance of moisture, suppression of weeds and addition of organic matter. It is noteworthy that there were values for dry matter higher than those recommended for the maize/green manure intercropping systems and maize monoculture.

The analyses of variance for maize production factors showed significant differences only for the variables final plant stand and average weight of 100 grains, with an isolated effect of the green manure sowing time on intercropping systems.

The highest plant stand was observed when the sowing of green manures was performed at the maize V4 stage (Table 3). Possibly, the maintenance of soil moisture provided by green manures, with a longer development time when seeded at this stage, allowed the establishment of a higher number of maize plants.

However, when comparing the intercropping of maize/green manure with maize monoculture, the contrasts between means revealed significant differences only for the treatment in which Calopogonium was sown at the maize V4 stage. This treatment resulted in a stand superior to the maize monoculture (Table 4).

Fontanetti et al. (2014) explained that Calopogonium has a higher soil moisture retention capacity. This was also confirmed by Teodoro et al. (2011), according to whom Calopogonium kept 
the most moisture in the soil, among the perennial Fabaceae studied.

Regarding the average weight of 100 grains, the result was the opposite to final stand, because the highest weight was found when green manures were sown at the maize VT stage, with an increase of approximately $4 \%$ in the weight of grains (Table 3 ). It is noteworthy that, regardless of the green manure species, the sowing at the maize V4 stage decreased the value of weight of 100 grains, in relation to the monoculture (Table 4).

According to Brachtvogel et al. (2009), the highest density of maize plants results in a more intra-specific competition, reducing the size of the ears and the number of grains, which become lighter.

Regarding prolificacy, only maize intercropped with tropical kudzu sown at the maize V4 stage showed no significant differences, when compared to the maize monoculture (Table 4). Apparently, the other intercropping systems allowed the production and the filling of more than one spike per plant, probably due to the best growing conditions in these systems,

Table 3. Averages for final plant stand and weight of 100 grains of maize, according to the time of sowing of green manure (V4 and VT).

\begin{tabular}{lcc}
\hline $\begin{array}{c}\text { Green manure } \\
\text { stage }\end{array}$ & $\begin{array}{c}\text { Final stand } \\
\left(\text { plant ha }{ }^{-1}\right)\end{array}$ & $\begin{array}{c}\text { Weight of 100 grains } \\
(\mathrm{g})\end{array}$ \\
\hline $\mathrm{V} 4$ & $69,814.8 \mathrm{a}^{1}$ & $31.5 \mathrm{~b}$ \\
$\mathrm{VT}$ & $61,481.5 \mathrm{~b}$ & $32.9 \mathrm{a}$ \\
\hline $\mathrm{CV}(\%)$ & 9.9 & 4.8 \\
\hline Average & $65,648.1$ & 32.2 \\
\hline${ }^{1}$ Means followed by the same letter, in the columns, do not differ statistically by \\
the Tukey test at $5 \%$.
\end{tabular}

Table 4. Averages for intercropping of maize/green manures treatments and significance of their contrasts with maize monoculture, for the variables final plant stand, prolificacy and average weight of 100 maize grains.

\begin{tabular}{|c|c|c|c|}
\hline Contrast & $\begin{array}{l}\text { Final stand } \\
\left(\text { plant ha }{ }^{-1}\right)\end{array}$ & Prolificacy & $\begin{array}{c}\text { Weight of } 100 \\
\text { grains }(\mathrm{g})\end{array}$ \\
\hline Calopogonium V4 & $72,777.8^{*}$ & $1.21 *$ & $32.16^{*}$ \\
\hline Calopogonium VT & $58,888.9^{\mathrm{ns}}$ & $1.23 *$ & $32.98^{\mathrm{ns}}$ \\
\hline Tropical kudzu V4 & $70,000.0^{\mathrm{ns}}$ & $1.17^{\mathrm{ns}}$ & $30.75 * *$ \\
\hline Tropical kudzu VT & $62,777.8^{\mathrm{ns}}$ & $1.23 *$ & $32.21 *$ \\
\hline Perennial soy V4 & $66,666.7^{\mathrm{ns}}$ & $1.26^{* *}$ & $31.65^{*}$ \\
\hline Perennial soy VT & $62,777.8^{\mathrm{ns}}$ & $1.29 * *$ & $33.48^{\text {ns }}$ \\
\hline Maize monoculture & $64,444.4$ & 1.07 & 34.54 \\
\hline
\end{tabular}

$*, * *$ and ${ }^{\text {ns }}$ Significant at $5 \%$ and $1 \%$ and non-significant, respectively, according to the $\mathrm{F}$ test. such as constant moisture. Von Pinho et al. (2009) reported that the increase in maize planting density reduces the prolificacy of plants, without, however, reducing grain yield. It was expected, therefore, that the competition established between maize and green manures and also the larger population of maize plants would reduce the number of ears per plant. However, this was not observed in this study.

The average grain yield showed no significant differences between the intercropping systems and maize monoculture, reaching $9.04 \mathrm{Mg} \mathrm{ha}^{-1}$, which is higher than the national harvest average (4.89 $\mathrm{Mg} \mathrm{ha}^{-1}$ ), in 2014/2015 (Conab 2016).

The lower plant stand found when green manures were sown at the maize VT stage (Table 3) was possibly offset by a higher average weight of grains (Table 3). In contrast, the lowest grain weight observed when the green manures were sown at the maize V4 stage (Table 3) was offset by a higher final plant stand (Table 3). No differences for grain yield were observed among treatments.

Matrangolo et al. (2014), conducting an experiment in the Brazilian Savannah, without fertilization and using the maize variety AL Avaré in monoculture and intercropped with jack beans, found yields between $3.85 \mathrm{Mg} \mathrm{ha}^{-1}$ and $4.30 \mathrm{Mg} \mathrm{ha}^{-1}$, respectively. The authors reported that the reduced yield may have occurred because of drought. Fontanetti et al. (2014), evaluating intercropped AL Avaré maize sown simultaneously with Calopogonium, at $35 \mathrm{DAE}$ of maize, obtained $3.60 \mathrm{Mg} \mathrm{ha}^{-1}$ and $3.44 \mathrm{Mg} \mathrm{ha}^{-1}$, respectively.

In this study, the perennial green manures evaluated did not affect the development and yield of maize grains, in the organic system. Green manures, in this case, may have contributed to soil protection and to the maintenance of moisture. In the medium term, they may also contribute to the addition of organic matter and nitrogen, through biological fixation, in association with bacteria of the Rhizobium genus, and, therefore, to the cycling of nutrients from the soil. They may also be used as a permanent soil coverage, or as forage, for the croplivestock integration.

\section{CONCLUSIONS}

1. Calopogonium provides the highest production of dry matter and soil coverage, when intercropped with maize, as well as a higher final plant stand 
than the maize monoculture, when sown at the fourth expanded maize leaf stage.

2. Perennial green manures grown intercropped with maize are not effective for controlling weeds in the organic system.

3. Calopogonium, tropical kudzu and perennial soy intercropped with maize do not affect the maize grain yield in the organic system.

\section{ACKNOWLEDGMENTS}

The authors are grateful to the Fundação de Amparo à Pesquisa do Estado de São Paulo (FAPESP) and Conselho Nacional de Desenvolvimento Científico e Tecnológico (CNPq), for supporting this study.

\section{REFERENCES}

ALVIM, K. R. de T. et al. Quantificação da área foliar e efeito da desfolha em componentes de produção de milho. Ciência Rural, v. 40, n. 5, p. 1017-1022, 2010.

BASI, S. Associação de Azospirillum brasilense e de nitrogênio em cobertura na cultura do milho. 2013. 50 f. Dissertação (Mestrado em Produção Vegetal) Universidade Estadual do Centro-Oeste, Guarapuava, 2013.

BEZERRA, A. P. A. et al. Rendimento, componentes da produção e uso eficiente da terra nos consórcios sorgo $\mathrm{x}$ feijão-de-corda e sorgo x milho. Ciência Agronômica, v. 38, n. 1, p. 104-108, 2007.

BORGHI, E.; CRUSCIOL, C. A. C. Produtividade de milho, espaçamento e modalidade de consorciação com Brachiaria brizantha em sistema de plantio direto. Pesquisa Agropecuária Brasileira, v. 42, n. 2, p. 163-171, 2007.

BRACHTVOGEL, E. L. et al. Densidades populacionais de milho em arranjos espaciais convencional e equidistante entre plantas. Ciência Rural, v. 39, n. 8, p. 2334-2339, 2009.

COELHO, A. M. Nutrição e adubação do milho. Sete Lagoas: Embrapa Milho e Sorgo, 2006.

COMPANHIA NACIONAL DE ABASTECIMENTO (Conab). Acompanhamento de safra brasileira de grãos, v. 3: safra 2015/16: 5 levantamento. 2016. Available at: $<$ http://www.conab.gov.br/OlalaCMS/ uploads/arquivos/15_08_11_08_55_08_boletim_graos_ agosto_2015.pdf>. Acces on: 4 Feb. 2016.

CRUZ, J. C. et al. Produção de milho orgânico na agricultura familiar. Sete Lagoas: Embrapa Milho e Sorgo, 2006.
FONTANETTI, A. et al. Milho orgânico em consórcio com calopogônio: produção de palhada para o plantio direto na entressafra. Cadernos de Agroecologia, v. 9, n. 4, p. 1-10, 2014.

INSTITUTO BRASILEIRO DE GEOGRAFIA E ESTATÍSTICA (IBGE). Censo agropecuário 2006: Brasil, grandes regiões e unidades da Federação. 2009. Available at: <http://www.ibge.gov.br>. Access on: 15 Jun. 2015.

LIMA, S. F. et al. Interferência de plantas daninhas no desenvolvimento de Fabaceas perenes. Revista Verde, v. 9, n. 4, p. 129-136, 2014.

MATRANGOLO, W. J. R. et al. Aspectos da produção orgânica de milho na região central de Minas Gerais. In: CONGRESSO NACIONAL DE MILHO E SORGO, 30., 2014, Salvador. Anais... Sete Lagoas: Associação Brasileira de Milho e Sorgo, 2014. p. 1-4.

MONQUERO, P. A. et al. Efeito de adubos verdes na supressão de espécies de plantas daninhas. Planta Daninha, v. 27, n. 1, p. 85-95, 2009.

MONTEIRO, E. M. M. et al. Valor nutritivo da leguminosa Pueraria phaseoloides como alternativa na suplementação alimentar de ruminantes na Amazônia Oriental. Ciência Rural, v. 39, n. 2, p. 613-618, 2009.

NUNES, U. R. et al. Produção de palhada de plantas de cobertura e rendimento do feijão em plantio direto. Pesquisa Agropecuária Brasileira, v. 41, n. 6, p. 943948, 2006.

OLIVEIRA, P. et al. Sistema Santa Brígida: consorciação de milho com leguminosas. Santo Antônio de Goiás: Embrapa Arroz e Feijão, 2010.

PADOVAN, M. P. et al. Pré-cultivo de adubos verdes ao milho em agroecossistema submetido a manejo ecológico no Cone Sul de Mato Grosso do Sul. Revista Brasileira de Agroecologia, v. 8, n. 3, p. 3-11, 2013.

PANTALEÃO, P. S. et al. Supressão de plantas daninhas pela cobertura com adubos verdes em solo de Cerrado. FAZU em Revista, n. 9, p. 30-43, 2012.

PERIN, A. et al. Desempenho agronômico de milho consorciado com feijão-de-porco em duas épocas de cultivo no sistema orgânico de produção. Ciência e Agrotecnologia, v. 31, n. 3, p. 903-908, 2007.

QUARESMA, M. A. L. et al. Leguminosas herbáceas perenes como plantas de cobertura de solo para cultivo de bananeiras em um luvissolo na Caatinga. Cadernos de Agroecologia, v. 8, n. 2, p. 1-5, 2013.

SEPROTEC. Forrageiras perenes. 2014. Available at: $<$ http://www.seprotec.com.br/sementes/forrageirasperenes.html>. Access on: 15 Jun. 2015.

SILVA, A. A. et al. Manejo de plantas daninhas no sistema integrado agricultura-pecuária. In: ZAMBOLIM, 
L.; FERREIRA, A. A.; AGNES, E. L. (Eds.). Manejo integrado: integração agricultura-pecuária. Viçosa: Universidade Federal de Viçosa, 2004. p. 117-169.

STEFANOSKI, D. C. et al. Uso e manejo do solo e seus impactos sobre a qualidade física. Revista Brasileira de Engenharia Agrícola e Ambiental, v. 17, n. 12, p. 13011309, 2013.
TEODORO, R. B. et al. Leguminosas herbáceas perenes para utilização como coberturas permanentes de solo na Caatinga Mineira. Ciência Agronômica, v. 42, n. 2, p. 292-300, 2011.

VON PINHO, R. G. et al. Avaliação agronômica do cultivo de milho em diferentes níveis de investimento. Ciência e Agrotecnologia, v. 33, n. 1, p. 39-46, 2009. 